Bulletin of Taras Shevchenko National University of Kyiv. Public Administration, 1(15), 16-19.

UDC: 351.

DOI: doi.org/10.17721/2616-9193.2022/15-3/9

Chengzhang Zou, Ph.D., Postdoctoral student,

Beijing Normal University, Beijing, China https://orcid.org/0000-0002-6425-3811 e-mail: 787234243@qq.com

\title{
THE PRINCIPLE OF PEACEFUL COEXISTENCE OF TWO SYSTEMS AS A DOCTRINE AFTER THE 20TH CONGRESS OF THE CPSU IN 1956
}

The purpose of the article is to analyze one of the key moments in the history of the Soviet Union - the 20th Congress of the Communist Party of the Soviet Union in February 14-25, 1956. The task is to investigate the relationship between the two main ideas that were expressed at the sessions of the Congress by $\mathbf{N}$. S. Khrushchev and party comrades: exposing the personality cult of J. V. Stalin and rethinking the idea of peaceful coexistence of the two systems, proposed by V. I. Lenin. The history of philosophy in Stalin's period, the struggle of dialectics with mechanists is analyzed, the influence of J. V. Stalin on changes in philosophy, which has acquired a dogmatic character thanks to the cult of personality, is demonstrated. Dialectics with its unity of opposites, being at the basis of all phenomena of nature and society, creates contradictions in the understanding of certain phenomena. That is why the concepts of "peace" and "war" acquire opposite connotations. After the exposure of the cult of personality, it is time for a new ideology, part of which is the recognition of terror in past and a peaceful orientation in foreign policy. The article analyzes the critical literature and transcripts of the congress' reports.

Keywords: 20th Congress of the Communist Party of the Soviet Union, the principle of peaceful coexistence of two systems, the history of Marxism, Soviet Philosophy, the history of the Communist Party of the Soviet Union.

Introduction. There was a period in the history of the Soviet Union when the country's official ideology changed its attitude towards to a diametrically opposite. This phenomenon went down in history as a condemnation of the personality cult and criticism of one ideology of another. The key process was the $20^{\text {th }}$ Congress of the Communist Party of the Soviet Union and the key event was the presentation of the First Secretary N. S. Khrushchev with his historic speech. The events of those years influenced not only the further fate of the Soviet Union but also other socialist countries. The Great Russian Encyclopedia literally emphasizes the doctrinal status of the idea of peaceful coexistence of the two systems for Soviet ideology: "After the $20^{\text {th }}$ Congress of the CPSU (1956), the policy of peaceful coexistence acquired doctrinal significance for the Soviet leadership, which remained until the end of the 1980s. At the same time, the concept of 'peaceful coexistence' has been eroded since the mid-1950s: in 1954, the PRC and India signed an agreement called 'Pancha Shila' ('five principles'), which interpreted peaceful coexistence as peaceful relations between states, and not between different world systems (later the Chinese leaders also declared their readiness to build relations with the USSR on the basis of peaceful coexistence). After the collapse of the world socialist system at the end of the 1980s, the term 'peaceful coexistence' is leaving the political vocabulary, retaining mainly in the historical and political context" [3].

The $20^{\text {th }}$ Congress of the CPSU was held in the winter of February 14-25, 1956 in the Big Kremlin Palace in Moscow. It is known from open sources that about 1500 delegates attended, representing more than 6 million party members and more than 400000 party candidates [1]. The congress was attended by delegations of communist and workers' parties from half a hundred foreign countries. All this testifies to the power of influence of the ideas put forward at the meetings and circulated in the proceedings of the meetings. In historical and ideological terms, it was the end of the Stalinist era, it made it possible to discuss the concept of "freedom", activated the communist ideals of the past. Theorists of Marxism argued that in the history of the USSR, for a long time there was a misinterpretation of the ideas of communism, and now the time has come for reflection and rethinking. It marked the weakening of ideological censorship in literature, art, and philosophy, which brought up many previously forbidden topics, and the return of many forbidden personalities. At a closed meeting of the CPSU Central Committee at the end of the congress, a speech was made criticizing the personality of $\mathrm{J}$. V. Stalin, it was argued that there was a cult in an atheistic country, and it was the cult of the leader's personality. They also discussed the state of affairs in the world, the role of socialism as a world system, its struggle against the enemy - imperialism. The collapse of the colonial system and the emergence of new developing countries were a kind of victory in this competition. However, it was a tactical, but not strategic victory, the strategy of the Soviet Union was the struggle for influence in these newly formed countries. In this regard, the Leninist principle of the possibility of peaceful coexistence of states with different systems was updated. In other words, the peaceful coexistence of the two systems.

The cult of personality and its influence on the principle of peaceful coexistence. The $20^{\text {th }}$ Congress of the CPSU adopted a decision on the variety of forms of transition of states to socialism. This diversity is a consequence of the development of the idea of a priori conflict with the possibility of peaceful alternatives. Civil wars are no longer, according to the official ideology, a necessary stage on the way to a new social formation. One of the first steps in criticizing Stalin's personality was a speech at the congress of A. I. Mikoyan, who criticized History of the Communist Party of the Soviet Union (Bolsheviks): Short Course (1938), even though J. V. Stalin was not personally mentioned in this speech. The essence of this speech is not so much in criticizing the personality of the leader as in demonstrating the strong influence of propaganda, misinterpreted philosophical ideas, and distortion of history. The chapter On Dialectical and Historical Materialism became a source of philosophical knowledge in the field of Marxism-Leninism, which contained only an official, verified interpretation of the main questions of the history of the party and Marxism-Leninism. Although it is possible that J. V. Stalin did not write the book, but he definitely wrote drafts for the philosophical chapter. He argues that the basis of Marxism is the doctrine of $\mathrm{G}$. Hegel about his system and dialectical method: "In characterizing their dialectical method, Marx 
and Engels usually refer to Hegel as the philosopher who formulated the main features of dialectics. This, however, does not mean that the dialectic of Marx and Engels is identical with the dialectic of Hegel. In fact, Marx and Engels took from Hegel's dialectics only its 'rational kernel', discarding the Hegelian idealistic husk and developing dialectics further in order to give it a modern scientific look" [10]. Further in the text there are words that confirm the connection between philosophy and politics: "This means that in order not to be mistaken in politics, it is necessary to pursue an irreconcilable class proletarian policy, and not a reformist policy of harmony of the interests of the proletariat and the bourgeoisie, and not a conciliatory policy of capitalism 'growing' into socialism. This is how matters stand with the Marxist dialectical method, if we take it as applied to social life, as applied to the history of society" [10].

This interpretation did not allow any arbitrary interpretation, only scholastic retransmission. The book The Harsh Drama of the People: Scientists and Publicists on the Nature of Stalinism (1989) contains articles that reevaluate the historical heritage, including Soviet philosophy. In the article The Suppression of Philosophy A. Ogurtsov writes: "Stalinism is, first of all, a regime of personal power, autocracy with its rejection of the democratic principles of social and political life, the unification of culture, a repressive ideology that was formed around the mythological cult of one Leader's personality and one value - Order" [7, c. 353]. The concept of "order" becomes an imperative, impossible without constant control, and control is not possible without violence. In its essence, this principle contradicts the possibility of peaceful coexistence not of two systems, but of the real existence of even one system. "Here politics was replaced by politicking, science - by serving utilitarian-pragmatic goals, philosophy - by the ideology of the elite, which became the helm of the power of the commandbureaucratic system, which itself was also suppressed by the despotic will of the autocrat. Stalinism did not need philosophy as a science. An objective, critical understanding of reality was completely alien to him, the very search for truth was unacceptable, for the latter had already been proclaimed 'a brilliant teacher and leader of all peoples'. Therefore, the 'already announced' truth had only to be repeated, memorized and commented on. It was on this 'cultivated' soil that the autocratic regime and authoritarian ideology grew, with its cult of the Leader, thoughtless faith in the wisdom of his decisions, with violence as the main method of educating a new person'" [7, c. 353]. With the advent of the Stalinist philosophers, it led to a drop in the level of philosophical work. This was noticeable in the sharp narrowing of the subject matter, and in the revision of all the former thinkers of the past. This problem was observed in the collection Hegel and Dialectical Materialism (1932), in the articles of M. B. Mitin Hegel and Dialectical Materialism, P. F. Yudin The Struggle on Two Fronts and Hegelian Dialectics, V. Raltsevich Hegel - the ideologist of the bourgeoisie, G. Bammel Hegel and modern bourgeois philosophy, V. Vandek, V. Timosko Hegel's struggle against materialism [5]. The narrative increasingly often contains the key words of the new ideology, which clearly have non-peaceful connotations: "struggle on two fronts", "ideologue of the bourgeoisie", "Hegel's struggle against materialism". Researcher A. Ogurtsov in his article The Suppression of Philosophy (1989) writes: "Its language is striking: 'open a Bolshevik fire', 'open a fierce battle', 'give a decisive rebuff', 'open a decisive fire', 'fight for the purity of our theoretical weapon', 'give a merciless rebuff to all attempts to blunt the edge of materialist dialectics', etc. The militarized style was supposed to create the image of the Enemy, to present yesterday's like-minded people, teachers and their own comrades as malicious enemies and direct ideological opponents. Such stylistic figures were used to 'sharpen weapons', which will soon be used not only against the theoretical and ideological cadres of the party, but also against their own people. Philosophy is literally becoming an ideological club, with the help of which the Stalinists completed the rout of freedom-loving philosophical thought, and put an end to even the smallest islands of independent theoretical research" [7].

In 1930s in Soviet philosophy, which formed the basis of ideology, there was a struggle between two groups: mechanists and dialectics. The first group included $L$. Axelrod and A. K. Timiryazev, A. Varyash, I. I. Skvortsov-Stepanov, V. Sarabyanov and others. Another group included A. M. Deborin, J. Stan, N. Karev, G. Bammel and others. "Just as the struggle within the party was waged on two fronts against the 'right' and against the 'left', just as in philosophy it was necessary to open two fronts, along with the struggle against the 'mechanists', a struggle should have begun on another front - against the 'Menshevik idealism"' [7]. The Soviet philosopher M. B. Mitin in his article Lenin and Philosophy gave an enthusiastic review of the book by the leader of Soviet philosophy A. M. Deborin Lenin as a Thinker (1924): "It is the best presentation of the philosophical views of Lenin, and thus of dialectical materialism" [6]. In the late 1930s, the situation changed, J. V. Stalin finally defeated the opposition currents in the party, and he began to assert his monopoly, implant the cult of his personality in all spheres of spiritual life. Philosophy was among the first victims of Stalinization. Researcher S. Korsakov writes A. M. Deborin refused to publish an article in which Stalin would be proclaimed as the great classical philosopher of Marxism. From the beginning of 1930s, the structures of the Central Committee began systematic pressure on A. M. Deborin. Head of Agitprop Central Committee A. I. Stetsky told the philosopher that now it is necessary to establish one authority in all sciences - Stalin. That is why M. B. Mitin and his supporters started an offensive against the A. M. Deborin's supporters. On June 7, 1930, the famous article was published by M. B. Mitin, V. N. Raltsevich and P. F. Yudin - On the new tasks of Marxist-Leninist philosophy (1930), in which political accusations were made against the A. M. Deborin's supporters. The main charge was that they ignored V.I. Lenin as a philosopher. This is only a special case, but it well illustrates the absurdity of what is happening, since in fact it was impossible to ignore the teachings of V. I. Lenin, but it was possible to blame it [6].

Thus, the cult of personality, which was announced at the $20^{\text {th }}$ Congress of the CPSU, was formed on the basis of Stalinist philosophy with its dialectical logic. Dialectics of materialism asserts the possibility of joint coexistence of opposites, and as it is known, the essence of dialectics is the struggle of opposites. In political terms, this meant striving for peace by military means. The ideas put forward by the Soviet leader and philosopher V. I. Lenin about the peaceful coexistence of two systems (socialism and capitalism) could not be realized under the conditions of Stalinist ideology.

Possibility of a peaceful path to a new social formation without war. "Lenin's principle peaceful coexistence of states with different social systems has been and remains the general line of our country's foreign policy". With such an ideological statement made at the $20^{\text {th }}$ Congress of the CPSU by First Secretary 
N. S. Khrushchev, this doctrine was supposed to determine the country's foreign policy and its philosophy in second half of $20^{\text {th }}$ century [1]. The end of the personality cult meant both the end of the previous ideology and the beginning of a new one. At the $20^{\text {th }}$ Congress of the CPSU, the authorities mistakes were named, the modest word "mistakes" means mass terror, persecution, and murder. In his dissertation for the degree of Doctor of Historical Sciences Lenin's principle of peaceful coexistence of two systems and the struggle of the CPSU and the Soviet government for its implementation at the present stage (1953-1956) (1957) researcher of the Kiev State University named after T. H. Shevchenko M. S. Zolotarev writes: "... The Central Committee of the CPSU and the Soviet government were not afraid to tell our people about the mistakes that our diplomacy made in the atmosphere of the cult of personality... Following Lenin's behests, the Party and the Government are pursuing a deeply principled and at the same time flexible foreign policy aimed at strengthening cooperation between peoples" [11, c. 328].

The main source of study of the main ideas announced at the Congress is the reports with transcripts published in 1956. Due to the large amount of materials, the verbatim report of the $20^{\text {th }}$ Congress of the CPSU is divided into two volumes. The first includes transcripts records of 1-12 sessions, the second - transcripts records of $13-20$ sessions, resolutions and appendices. At the beginning of his speech, First Secretary N. S. Khrushchev talks about the successes in domestic politics: "In the field of domestic politics, these were the years when the party, proceeding from the interests of the whole people, critically assessing the situation in agriculture and industry, it took a number of serious measures in order to rely on the successes achieved to take a new major step forward in the socialist development of the country" [1, c. 9]. Following the announcement of the achievements of domestic policy, N. S. Khrushchev announced that during the reporting period between the Congresses, economic growth has been observed. In agriculture and in the economy, the party took a number of measures that contributed to the achievement of success and the growth of the welfare of the socialist country.

In addition, N. S. Khrushchev reported the following about the successes in foreign policy: "During the reporting period, important events took place in the field of foreign policy. The tensions in international relations fraught with great dangers, thanks to the consistently peaceful foreign policy of the countries of the socialist camp, gave way to a certain detente. Precisely because the Soviet Union, together with its friends, the People's Republic of China and other People's Democracies, timely launched a series of consistent foreign policy measures supported by all peaceloving forces, real prospects for the better opened up in the international arena" [1, c. 9]. Analyzing the speech it is clear that the party considers the wisdom of the MarxistLeninist teaching on which the party's activity is based.

Above in the text, the number of countries participating in the Congress was mentioned, but it is worth recalling the very problematic relationship between the official ideology and the concept of the nation. If we talk about the peaceful coexistence of systems, then at first glance, the problem of "nation" fades into the background, but this is not entirely true. In their research S. V. Rudenko and V. Y. Vilkov come to conclusions, they write in their article De-Stalinization of the Concept of the Nation in Soviet Marxism in the Second Half of the $20^{\text {th }}$ Century (2020) about some problems of Soviet philosophy through the prism of contemporary philosophy: "The reasons for the ideologization of the re- search work of Soviet scientists and their accessible results (accessible to all citizens, rather than a limited group, especially in the 1980s), were that the theory and concept of the nation were of traditional interest not only for Marxism as a science. They also performed such important, for the political system and power in the USSR, functions as: the theoretical substantiation of the system of regulatory and legal statuses of ethno-national communities (nations, ethnic groups, ethnic minorities) in the Soviet Union; scientific apology of the party strategy of 'bringing nations together under socialism'; the development and popularization in the mass consciousness of the ideology of the 'new historical community' - 'the Soviet people'; ideological, theoretical and methodological support for the propaganda work of the CPSU and its structures and, in general, the struggle of the institutionalized power of the Soviets against the manifestations of 'bourgeois nationalism'; conducting counterpropaganda against all non-Marxist or anti-Marxist ideas, theories, ideologies and philosophies that were created in the West and were considered hostile to the 'matter of socialism and communist building', the victory of the national liberation movements of oppressed peoples, especially in developing countries" [9, c. 162].

It is noticeable how the narrative changes, instead of mentioning enemies, friends appear, instead of militant rhetoric, concepts appear "peaceful foreign policy", "friends", "peace-loving force". The statements made by the leadership of the Communist Party call for peace. Indeed, steps were taken to radically improve SovietAmerican relations. The rhetoric of the party is that it is not the Soviet Union needs the peaceful coexistence of two systems, but the whole world is waiting for the peaceful coexistence of the two superpowers. As an argument, the reference is often made to the "arms race", "a dangerous build-up of forces". To replace the slogan "Let's arm ourselves!" comes the slogan "Let's trade!". It was with the development of economic relations that the Soviet Union saw the possibility of maintaining peace, according to the official ideology. "To strengthen the cause of world peace, it would have enormous the importance of establishing strong friendly relations between the two largest powers in the world - the Soviet Union and the United States of America. We believe that if the well-known five principles of peaceful coexistence were the basis of relations between the USSR and the United States, this would have truly outstanding significance for all mankind and would, of course, be useful to the people of the United States no less than the peoples of the USSR and all other peoples. These principles - mutual respect for territorial integrity and sovereignty, non-aggression, non-interference in each other's internal affairs, equality and mutual benefit, peaceful coexistence and economic cooperation - are now shared and supported" [1, c. 31-32].

The meeting was attended by the First Secretary of the Central Committee of the Socialist Unified Party of Germany, W. E. P. Ulbricht, in his report he touched upon the topic of philosophy and ideology. As a graduate of the International Lenin School, he knew the foundations of Marxism-Leninism well, understood the philosophy and history of the party. In his speech, he gives interesting formulations: "Comrade N. S. Khrushchev stressed that thanks to the might of the Soviet Union, the states of the socialist camp, and thanks to the strength of the peace camp, there are real possibilities for ensuring peace ... Representatives of capitalist ideology admit that they cannot oppose anything to Lenin's ideology; that is why they seek to pervert dialectical and historical materialism ... In the midst of the great ideological struggle 
currently taking place between representatives of both social systems, it is our duty to direct our propaganda work towards a more persistent struggle than until now" [1, c. 300-301].

\section{References}

1. $20^{\text {th }}$ Congress of the CPSU (February 14-25, 1956): Transcript report. Vol. 1. Moscow : Gospolitizdat, 1956a. 640 p.

2. $20^{\text {th }}$ Congress of the CPSU (February 14-25, 1956): Transcript report. Vol. 2. Moscow : Gospolitizdat, 1956b. 560 p.

3. Barishpolets V. A. Peaceful Coexistence. Great Russian Encyclopedia: in 30 volumes. Volume 20: Meotskaya archaeological cultureMongol-Tatar invasion. Moscow : Great Russian Encyclopedia, 2012 . 766 p.

4. Deborin A. M. Lenin as a Thinker. Moscow: Krasnaya nov, 1924. 88 p

5. Hegel and Dialectical Materialism. Moscow : Partizdat, 1932. 276 p.

6. Korsakov S. Mitin (Gershkovich) Mark Borisovich. Scientists of the Academy of Sciences. 1920s-1950s. Collection of portraits of the photographer M. S. Nappelbaum with biographical information. Moscow : Institute of the History of Natural Science and Technology RAS, 2010. 591 p.
7. Ogurtsov A. P. The Suppression of Philosophy. The Harsh Drama of the People: Scientists and Publicists on the Nature of Stalinism / Eds. Yu. P. Senokosov. Moscow : Politizdat, 1989. 512 p.

8. On the New Tasks of Marxist-Leninist Philosophy (co-authored with V. N. Raltsevich, P. F. Yudin). Pravda. 1930. 7 June.

9. Rudenko, S., Vilkov, V. (2020). De-Stalinization of the Concept of the Nation in Soviet Marxism in the Second Half of the 20th Century. Politické Vedy. Vol. 23. No. 4. P. 160-195. https://doi.org/10.24040/ politickevedy.2020.23.4.160-195

10. Stalin J. V. About Dialectical and Historical Materialism. Works. T. 14 Moscow : Publishing House "Pisatel", 1997. P. 253-282.

11. Zolotarev, M. S. (1957). Lenin's principle of peaceful coexistence of two systems and the struggle of the CPSU and the Soviet government for its implementation at the present stage (1953-1956). Candidate's thesis. Kyiv.

Received: December 03, 2021 Approved for printing: December 29, 2021 Published: January 31, 2022

Вісник Київського національного університету імені Тараса Шевченка. Державне управління, 1(15), 16-19.

Удк:351

DOI: https://doi.org/10.17721/2616-9193.2022/15-3/9

Ченгжанг Жоу, д-р філос., докторант

Нормальний університет Пекіна, Пекін, Китайська Народна Республіка https://orcid.org/0000-0002-6425-3811

e-mail: 787234243@qq.com

\section{ПРИНЦИП МИРНОГО СПІВІСНУВАННЯ ДВОХ СИСТЕМ ЯК ДОКТРИНА ПІСЛЯ XX 3'ЇЗДУ КПСС У 1956 РОЦІ}

Проаналізовано один із ключових моментів в історії Радянського Союзу - XX з'їд Комуністичної партії Радянського Союзу 1425 лютого 1956 р. Досліджено взаємозв'язок між двома основними ідеями, висловленими на засіданнях з'їду Н. С. Хрущовим та товаришами по партї: розкриття культу особистості Й. В. Сталіна та переосмислення ідеї мирного співіснування двох систем, запропонованої В. І. Леніним. Проаналізовано історію філософії сталінського періоду, боротьбу діалектики з механістами, продемонстровано вплив Й. В. Сталіна на зміни у філософії, яка набула догматичного характеру завдяки культу особистості. Діалектика з їі єдністю протилежностей, що лежить в основі всіх явищ природи та суспільства, породжує суперечності в розумінні тих чи інших явищ. Саме тому поняття "мир" та "війна" набувають протилежних конотацій. Після викриття культу особистості настав час нової ідеології, частиною якої є визнання терору в минулому та миролюбна орієнтація у зовнішній політиці. Проаналізовано критичну літературу та стенограми доповідей з 'ізду.

Ключові слова: XX з'їд Комуністичної партії Радянського Союзу, принцип мирного співіснування двох систем, історія марксизму, радянська фрілософія, історія Комуністичної партії Радянського Союзу. 